\title{
Process Ownership Challenges in IT-Enabled Transformation of Interorganizational Business Processes
}

Holm Larsen, Michael; Klischewski, Ralf

Document Version

Final published version

Publication date:

2003

License

CC BY-NC-ND

Citation for published version (APA):

Holm Larsen, M., \& Klischewski, R. (2003). Process Ownership Challenges in IT-Enabled Transformation of Interorganizational Business Processes.

Link to publication in CBS Research Portal

\section{General rights}

Copyright and moral rights for the publications made accessible in the public portal are retained by the authors and/or other copyright owners and it is a condition of accessing publications that users recognise and abide by the legal requirements associated with these rights.

\section{Take down policy}

If you believe that this document breaches copyright please contact us (research.lib@cbs.dk) providing details, and we will remove access to the work immediately and investigate your claim. 


\section{Process Ownership Challenges in IT-Enabled Transformation of Interorganizational Business Processes}

\author{
Michael Holm Larsen \\ Department of Informatics, \\ Copenhagen Business School \\ Tel.: +45-3815-2385 \\ E-mail:mh.inf@cbs.dk
}

\author{
Ralf Klischewski \\ Department of Informatics, Hamburg University \\ Vogt-Koelln-Strasse 30, D-22527 Hamburg \\ Tel.: +49-40-42883-2299 \\ E-mail: klischewski@informatik.uni-hamburg.de
}

\begin{abstract}
The paper investigates the challenges of process ownership in business processes crossing organizational boundaries. A literature review explores the research traditions of business process reengineering, interorganizational systems (IOS), workflow management, and system development with regard to process ownership and the changing role from intraorganizational issues to interorganizational issues. The result is a list of relevant process owner tasks, classified by different issues in which a shift of focus is suggested.

A case study of a governmental process portal serves the purpose of exemplifying the novel process ownership challenges in an interorganizational context. Analyzing the case form the process ownership perspective reveals that the proposed shift of focus is indeed applicable and how neglecting these new challenges are a barrier for successful transformation.

With the categorization and shift of focus suggested in this paper, future research may investigate in more detail the dilemmas of distributed versus centralized ownership and bring out different models of interorganizational process ownership to support handling the related issues in an integrated way.
\end{abstract}

\section{Introduction}

Spreading out and maturity of internet technology has opened up new opportunities for supporting interorganizational processes - and companies as well as governments are seeking for the best way to take advantage of this. Lessons learned from process management within organizations reveal that development and implementation of information technology (IT) for process support is most beneficial when embedded in a strategy of business process redesign and organizational change. Basically, this essential applies to process management between organizations just the same, and we already find several research areas (e.g. supply chain management, business networking) addressing those issues. However, all of these approaches assume that the responsibility for process management and process design rest in one hand, i.e. one powerful actor is able to organize and direct how all other actors involved participate in and/or accept the results of BPR and the setup of IT support. Usually this actor is referred as the "process owner'.

Unambiguousness in process ownership seems to be one of the critical success factors of combining IT support and business process redesign (Hammer 1996). However, in many inter-organizational settings (such as e-government, health care processes, educational programs, service industry) business processes are only sparsely structured and formalized, rather loosely coupled, and/or based on ad hoc cooperation - and often there is no explicit or implicit agreement of process ownership.

This research is an explorative study with the overall research task of a cross-disciplinary analysis of process ownership issues in an interorganizational context. To examine the issues of interorganizational process ownership more closely we seek to answer the following research questions:

- What are the tasks of a process owner?

- What is a relevant classification of process ownership tasks and challenges?

- What is the difference between intra-organizational and inter-organizational process ownership tasks and challenges?

As there are no recipes available for managing process ownership challenges under various circumstances, an investigation of established literature is undertaken in order to extract learning points and principles from four bodies of knowledge: business process management and business networking, interorganizational systems and standardization, workflow management, and system development. These literature bodies are chosen because 
they all incorporate process owner issues either from a technological or business perspective.

After extracting the process ownership issues from existing research, these are classified based on the nature of their origin, and hereby determining dimensions of process ownership. These dimensions are considered in an intraorganizational and interorganizational context, and a set of metaphors is suggested to point out the shift of focus within these dimensions.

This set of metaphors is then used to analyze process ownership issues in a case of an IT-enabled transformation of an interorganizational process. Besides demonstrating the feasibility and analytical power of this approach, we are interested in how this could lead to insights into success factors of interorganizational process transformation.

Finally, we point out how future research may investigate in more detail the dilemmas of distributed versus centralized ownership to bring out guidelines for practitioners with respect to characteristics of actors' cooperation and the interorganizational processes at stake.

\section{Findings in Process Ownership Research}

The literature review will explore the research traditions of system development, interorganizational systems (IOS), workflow management, and business process reengineering and management.

\subsection{Business Process Reengineering}

Reengineering, redesign, business process reengineering among other names represent radical improvements methods in organizational efficiency and performance (Hammer 1990, Davenport 1993, Schnitt 1993, Larsen \& Leinsdorff 1998, Larsen 2002). A business process may be defined as "... a set of logically related tasks performed to achieve a defined business outcome" (Davenport \& Short 1990) or as “... activities that takes one or more kinds of input and create an output that is of value to the customer" (Hammer \& Champy 1993).

Venkatraman (1994) suggest a framework categorizing transformation methods in the dimensions of range of potential benefits, i.e. scope of the project, and degree of business transformation. Here the notion Business Network Redesign (BNR) is proposed for transformation projects with a high degree of business transformation, which has direct implication for the logic of business scope and the consequent redistribution of revenue and profit margin streams in a given market (pp. 84).
Moreover, BNR implies that tasks and business processes may be expanded or restructured across organizational boundaries, often facilitated by information technology (Kambil \& Short 1994). Venkatraman (1994) stress the objectives of seeking efficiency and enhancing capabilities, but does not investigate the challenges of process ownership either in an intra- or interorganizational context. Larsen \& Bjørn-Andersen (2001) introduce the concept of a flowmaker, who should facilitate a business process in an organization that deliberately has chosen a functional structure though recognizing the importance of process efficiency and effectiveness.

Hammer \& Champy (1993) and Hammer \& Stanton (1995) use the notion of a process owner to identify the person responsible for the reengineering of a specific process, including establishing the standards of performance. Hammer (2002) states that the process owner needs to ensure that the people performing the process understand it, are trained in it, have the required tools and are following the specified design (p. 27). Moreover, the process owner establishes the process design, ensures that the design is followed, obtains resources that the process requires, establishes and implements the necessary supporting tools facilitating the process, ensures an ongoing high performance, and intervenes as needed to improve the process. Hence, the process owner must have the end-to-end accountability for a process (Hammer 2001a:65). The process owner is appointed by the leader of the organization. The process owner must have the authority and the personal clout to get all departments involved in the process to make necessary changes (Hammer \& Champy 1993:99). In order to keep the process owner personally motivated, performance of the process owner must be directly related to the performance of the process itself.

The early reengineering literature does not recognize the interorganizational context of business transformation, whereas the issue becomes highly important towards the end of the decade (e.g. Hammer \& Stanton 1999, Keen \& McDonald 2000, Porter 2001).

Hammer (2001b) also investigates interorganizational redesign. However, the issue of process ownership is only addressed indirectly through setting up a executive steering committee in the organizing phase of a project, where the leaders from both companies should define each company's investment, roles, and share of benefits. Furthermore, they should establish the rules of engagement and procedures for resolving disputes, and establish performance measures and goals. In addition to this, it is suggested that the entire process should be designed as one unit. 
Champy (2002) suggests the concept of X-engineering (x: cross). X-engineering is reengineering put into an interorganizational context, i.e. "crossing" organizational boundaries with suppliers, partners and customers with the aim of improving operations across organizations and establishing or enabling new value propositions for customers. Champy (2002) proposes the X-engineering triangle, i.e. the three P's: process, proposition and participation, which is reinvented by $\mathrm{X}$-engineering. In examining the latter $\mathrm{P}$, Champy (2002: 34, 124, 127) poses questions to determine the scope of the X-engineering endeavor: how extensively do you plan to cross organizational boundaries to harmonize the processes with those of your customers, suppliers, partners and even competitors, how many different kinds of organizations do you want or need to involve in the redesign and $\mathrm{X}$ engineering of your business and operations, who will you participate with you in X-engineering and in the creation and delivery of your business proposition, what partners do you want to involve in your business redesign and operations, how far should you go in integrating your processes? These questions are all fundamental management challenges of process ownership in regard to interorganizational processes. Champy (2002: 122-142) suggests four levels of participation, where level 1 represents the X-engineering of internal processes of the organization. This is similar to reengineering or business process reengineering, as known from the 1990's, but focuses on electronic tools that enable structural transformations. Level 2, 3 and 4 progresses successively to more complexity, challenge and opportunity by redesigning the business processes along with the processes of either one, two or three types of organizations, i.e. customers, suppliers, and partners.

Champy (2002: 140-141) suggests some principles that are of importance when collaborating with organization through harmonizing the process across organizations:

- Understand and respect the business goals of the partners.

- Be prepared to enter an active negotiation about the joint development of new business propositions and process redesign.

- All partners should recognize the contributions of the process owners in their organizations.

- Maintain an open communication environment where you and your partners jointly assess your performance.

- Close the loop on all agreed actions.

- Set objectives and measures for the fulfillment of agreed actions

- Select partners who share your values.
- Find partners with complementary offerings.

- Find partners who will create the changed and improved value proposition for your customers.

- Create combinations that will reduce the need for capital, not require more.

The various recommendations (on different abstraction levels) will be presented in a structured list in section 3 . The field of tension between these rather idealized principles and project reality will be discussed in section 4 .

\subsection{Interorganizational Systems}

Interorganizational information systems (IOS) research is a research tradition that sat it's roots for more than two decades ago (Barret \& Konsynski 1982, Porter \& Millar 1985, Johnston \& Vitale 1988, Konsynski \& McFarlan 1990, Benjamin et al. 1990, Lee \& Clark 1996). IOS is a concept that spans from EDI to electronic markets and business system networks incorporating multiple interrelated organizations (Meier \& Spargue 1991, Larsen et al. 1999). Although, EDI only is a subpart of IOS, it is a dominating body of knowledge, which has several lessons to learn from. Hence, focus in this section is primarily on EDI. The aim is to control information flows and decision making in an interorganizational system encompanssing several hierarchically arranged organizations, cf. Holland (1995: 123). Traditionally, IOS research assumes a value chain perspective, and hereby electronically linking business-to-business operations in bilateral relations, which often are based on EDI (Clarke 1992, Krcmar et al. 1995). Hence, the IOS literature does not support thinking of $\mathrm{n}$-to-n relations, multi-lateral electronic or market relations.

Moreover, IOS research tends to assume and facilitate shared information systems between companies to support cooperative strategies (Holland \& Lockett 1993, Short \& Venkatraman 1992). Hence, the prerequisite for ownership of the shared interorganizational business process is that responsibility and control are not mastered or facilitated by a single authority. Instead responsibility and control are executed as far as agreements such as service level agreements and general business practice allow.

Implementing and IOS may also impact on the organizational boundaries and flexibility (Meier 1995). Although IOS may provide significant opportunities for organizational redesign and enhance of service responsiveness (McFarlan 1984, Rogers et al. 1992, Mukhopadhyay et al. 1995), the mutual dependence between the participating organizations of the IOS may lead to reduced organizational flexibility. 
The implications of the potentially restrictive influence are that the IOS potentially limits their adaptability of both the user and provider organization (Meier 1995).

Clemons \& Row (1992) argue that an organization that is not the system owner may become locked into the system by high switching costs due to extensive investments related to the purchase and deployment of the information system. This may impose constraints on the participant's strategy as e.g. a retailer that is connected to a wholesaler's IOS may be depended the system not only for ordering supplies but in addition to this for managing their inventories, accounting, and handling their shelfstocking logistics (Meier 1995: 138-139). Under these circumstances, the retailer's organization is actually designed around the standards and technological options of the wholesaler's interorganizational system, which implies that the freedom to change or redesign the organization depends to a large extent on the compatibility of such changes with the IOS.

As mutual dependence between the participating organizations of the IOS potentially limits their ability to change, management of relations on key operations issues are necessary, which to some extent may relay on trust (Skagen 1989). Moorman et al. (1992) regards trust in two distinct ways. Trust may be viewed as belief or expectation about a partner's trustworthiness based on experience, reliability, or intentionality. Moreover, trust may be defined as a reliance on a partner that involves vulnerability and uncertainty, which are the exact characteristics of the business partners of the shared business process connected by the interorganizational information system due to the mutual dependence of the organizations. Hence, trust is a necessary condition for the decision making power and shared process ownership of an interorganizational business process.

The allocation of power between the business partners may, however, not necessary be equally distributed (Meier 1995, Webster 1995). Hence, the conditioning of the design of the IOS may depend on non technical and rational processes but on economic and political processes in articulating interests, building alliances and struggling over outcomes (Webster 1995: 31). The implications of this, cf. Bar et al. (1989) is that network and business process control may be more important than network and business process ownership, and critical to the securing of competitive advantage. This kind of interorganizational influence or negotiation power (Porter 1979, 2001), may be exercised with different degrees of refinement (Oliver 1990, Williams 1997) varying from coercion where an organization proclaim that after a certain date, the use of EDI is a precondition for a continued business relation- ship, to compensation with shared benefits, to partnership where risks and opportunities are shared (NygaardAndersen \& Bjørn-Andersen 1994: 204-205).

\subsection{Workflow Management}

The area of workflow management seems to be the perfect linkage between BPR and IT support because through process (workflow) modeling it seeks to separate the process design from implementing the necessary IT support. The Workflow Management Coalition defines workflow as the "automation of a business process, in whole or part, during which documents, information or tasks are passed from one participant to another for action, according to a set of procedural rules" (Allen 2000, p. 15). Workflow management focuses on the IT support for work processes in a given infrastructure, and not on the business values (as in BPR).

For a number of years the research on workflow management has focused also on interorganizational issues such as coupling of workflows (Aalst 2000), contracting of workflows (Grefen et al. 2000, Dijk 2003), expanding Petri net application (Aalst et al. 1999), support through XML based schema definition (Aalst \& Kumar 2003), web services for workflow (Lienhard 2003), Business Process Execution Language for Web Services (Andrews et al. 2003), and use of other standards (as sought by the Workflow Management Coalition, cf. Anderson \& Allen 1999).

The basic characteristic of interorganizational workflow is the a priori absence of end-to-end process control. This has led workflow research to focus on interoperability issues which are related to the different modes such as chained processes, nested sub-process, and parallel synchronized processes. Problems to be encountered on the way to workflow interoperability are mainly (cf. Zhao 2002)

- autonomy of local workflow processing

- difference in levels of local workflow automation (e.g. degree of implementation and IT support)

- variation in workflow control policy

- confidentiality prevents complete view of workflow

- low interoperability due to heterogeneity in hardware, software, and modeling in multiple organizations

- lack of cross-company access to workflow resources In consequence, the absence of end-to-end process control, which is often related to the absence and/or limits of a single overall process ownership, has led workflow research to reexamine and to find new ways for workflow composition. The research agenda now focuses on con- 
tracting and standardization of functionality and interfaces of process parts as services, based on a cooperative environment. However, one of the basic obstacles is the lack of a comprehensive model of interorganizational business processes as a basis for contracting and standardization.

Summing up, the future of interorganizational workflow is highly depending on those issues which are related to a common understanding of the specific business issues involved. Basu \& Kumar (2002, p. 4) acknowledge that "unfortunately, most of today's workflow management systems [...] oversimplify the organizational dimension" and call for more research in that direction. In discussing interorganizational workflows for e-business, they also call for "techniques for ensuring semantic integrity of the information and rules for mapping it correctly between any two partners" (ibid., p. 11). Advances in Semantic Web and intelligent systems might resolve some of the issues in the future, but for the innovation and implementation of new processes human agency will be indispensable.

\subsection{System Development}

While the interrelation of IT and IS development and organizational change is widely acknowledged by IT experts, the dynamics of change and BPR projects in particular are peculiar challenges to IS projects because it is so hard to specify requirements for the IT development. Actually, there is only little overlap between research in BPR and systems analysis (one notable exception is Jacobson 1992), so that so far there is no shared vocabulary and perspective, and only little effort to integrate both fields (cf. Weerakkody \& Currie, 2003).

Similarly, there is only limited discussion of IOS development issues represented in the literature (cf. Ramanath et al. 1997) although one might assume that understanding of the IOS development process is prerequisite for achieving effective systems.

Whenever possible, the dynamics of process (re-)design are delegated to external concepts such as workflow management (see above) or adaptation of predefined reference models (e.g. when introducing an ERP system such as SAP R/3).

When interorganizational systems development is characterized by the absence of an overall IT management, the development unlikely to result in one integrated IT system to support interorganizational processes. Instead, the actors involved start to focus on an information infrastructure to support their cooperation and the interoperability of the local systems (cf. Ciborra 2000, Klischewski 2001).
If, to some extent, participation of all/several actors is needed for development of commonly used components (e.g. server functionality, process patterns), interorganizational efforts (compared to intra-organizational projects) need to emphasize and secure actors' commitments to the interorganizational systems development (Klischewski 2001a).

Just as in the areas discussed above, the absence of an overall IT management brings out new key issues such as cooperation, contracting, and trust, while at the same time the individual contribution is increasingly rendered to be visible and contractible at the interface.

\section{Process Ownership Challenges}

The following table rephrases the insights from the literature review above into tasks of the process owner, classified by the nature of the issues that the process owner needs to tackle:

\begin{tabular}{|c|l|}
\hline \multicolumn{2}{|c|}{$\begin{array}{l}\text { Process Owner Tasks } \\
\text { in an Interorganizational Transformation Process }\end{array}$} \\
\hline Issues & \multicolumn{1}{c|}{ Related Process Owner Task } \\
\hline Environment & $\begin{array}{l}\text { - Set the environment for the process owner } \\
\text { - Define process owner scope - responsible for the } \\
\text { reengineering of a specific process - with end-to-end } \\
\text { accountability } \\
\text { - Define (or assure existence of performance } \\
\text { schemes, which are directly related to the } \\
\text { performance of the process itself }\end{array}$ \\
\hline Valiness & $\begin{array}{l}\text { - Assure/facilitate for business outcome } \\
\text { - Seek efficiency and enhance capabilities } \\
\text { - Understand and respect the business goals of the } \\
\text { partners } \\
\text { - Identify risks and opportunities, and how these are } \\
\text { needs to be shared between business partners }\end{array}$ \\
\hline Process & $\begin{array}{l}\text { Secure logically related tasks } \\
\text { - Design the entire process as one unit } \\
\text { - Identify extent of which the processes should be } \\
\text { integrated } \\
\text { - Specify control of information flows and decision } \\
\text { making in an interorganizational system } \\
\text { - suggest/develop service level agreements } \\
\text { - Identify issues of mutual dependence between } \\
\text { business network partners } \\
\text { - Specify organizational flexibility and adaptability } \\
\text { requirements } \\
\text { - Specify swot of eventual lock-in situations with } \\
\text { regard to switching costs and investments related to } \\
\text { the purchase and deployment of the information } \\
\text { system } \\
\text { - Identify procedural rules for workflow } \\
\text { - Assure robustness of workflow (e.g. simulate) } \\
\text { - Identify web services for the workflow } \\
\text { - Identify level of access to workflow resources }\end{array}$ \\
\hline
\end{tabular}




\begin{tabular}{|c|c|}
\hline $\begin{array}{l}\text { Information } \\
\text { Technology }\end{array}$ & $\begin{array}{l}\text { - Identify role of IT } \\
\text { - Facilitate shared information systems between } \\
\text { companies to support cooperative strategies } \\
\text { - Provide standard of information structure (e.g. XML } \\
\text { schema definition), i.e. ensuring semantic integrity } \\
\text { of the information and rules for mapping it correctly } \\
\text { between any two partners } \\
\text { - Identify interoperability issues } \\
\text { - Determine requirements for the IT development } \\
\text { - Understand the IOS development process } \\
\text { - Adapt at predefined reference models (e.g. when } \\
\text { introducing an ERP system such as SAP R/3) } \\
\text { - Assure overall IT management } \\
\text { - Emphasize and secure actors' commitments to the } \\
\text { interorganizational systems development }\end{array}$ \\
\hline $\begin{array}{l}\text { Trans- } \\
\text { formation } \\
\text { Process } \\
\text { (Redesign \& } \\
\text { Change } \\
\text { Management) }\end{array}$ & $\begin{array}{l}\text { - Identify the freedom to redesign the organization } \\
\text { depending on the compatibility of the changes with } \\
\text { the IOS. } \\
\text { - Define degree of business transformation } \\
\text { - Define business scope of the transformation } \\
\text { - Find partners who will create the changed and } \\
\text { improved value proposition for your customers, who } \\
\text { will share your values and have complementary } \\
\text { offerings. } \\
\text { - Identify scope for participation (of business value } \\
\text { network actors) } \\
\text { - Be prepared to enter an active negotiation about the } \\
\text { joint development of new business propositions and } \\
\text { process redesign. } \\
\text { - Maintain an open communication environment } \\
\text { where you and your partners jointly assess your } \\
\text { performance. } \\
\text { - Close the loop on all agreed actions. } \\
\text { - Set objectives and measures for the fulfillment of } \\
\text { agreed actions } \\
\text { - Understand several hierarchically arranged } \\
\text { organizations } \\
\text { - Think in n-to-n relations, multi-lateral electronic or } \\
\text { market relations. } \\
\text { - Identify potential conflicting issues (channel } \\
\text { conflicts, pricing, decision making power, etc.) } \\
\text { - Establish/review workflow control policy } \\
\text { - Contract and standardize functionality and inter- } \\
\text { faces of process parts as services } \\
\text { - Determine how many different kinds of } \\
\text { organizations do you want or need to involve in the } \\
\text { redesign and X-engineering of your business and } \\
\text { operations } \\
\text { - Identify business value network actors (suppliers, } \\
\text { partners, customers, competitors) } \\
\text { - Suggest/establish the rules of engagement and } \\
\text { procedures for resolving disputes } \\
\text { - Assure that all partners should recognize the contri- } \\
\text { butions of the process owners in their organizations } \\
\text { - Create combinations that will reduce the need for } \\
\text { capital, not require more. } \\
\text { - Identify trust and bargaining power issues in partner } \\
\text { network } \\
\text { - Manage relations with partners }\end{array}$ \\
\hline
\end{tabular}

Table 1: Process Owner Tasks.
For many of those tasks the literature mentions a shift of scope, focus and/or emphasis when addressing the transformation of interorganizational processes instead of ("only") intraorganizational processes. To point out these new challenges, we suggest using the following set of contrasting descriptions, which pin-point the changes in locus for each of the process ownership focus areas (see table 2).

We will now use this set of contrasting descriptions to analyze process ownership issues in the case of an ITenabled transformation of an interorganizational process. Besides demonstrating the feasibility and analytical power of this approach, we are interested in how this could lead to insights into success factors of interorganizational process transformation.

\begin{tabular}{|c|c|c|}
\hline \multirow{2}{*}{$\begin{array}{l}\text { Process } \\
\text { Ownership } \\
\text { Focus }\end{array}$} & \multicolumn{2}{|c|}{ Locus of Process Ownership } \\
\hline & Intra-organization & Inter-organization \\
\hline Environment & $\begin{array}{l}\text { Single organization } \\
\text { (with departments) }\end{array}$ & $\begin{array}{l}\text { Network of } \\
\text { organizations }\end{array}$ \\
\hline Business Value & Customer Value & Partner Value \\
\hline $\begin{array}{l}\text { Process } \\
\text { Specification }\end{array}$ & $\begin{array}{l}\text { Tasks connected by } \\
\text { rules }\end{array}$ & $\begin{array}{l}\text { Services connected } \\
\text { through interfaces }\end{array}$ \\
\hline $\begin{array}{l}\text { Information } \\
\text { Technology }\end{array}$ & System & Infrastructure \\
\hline $\begin{array}{l}\text { Transformation } \\
\text { Process }\end{array}$ & Process definition & $\begin{array}{l}\text { Process negotiation \& } \\
\text { contracting }\end{array}$ \\
\hline
\end{tabular}

Table 2: Shift of locus and focus in process owner tasks.

\section{The Case Study of an e-Government Process Portal}

In the case reported here, the city state of Hamburg, Germany, sought to take advantage of potentials of internet technologies. The case has been highlighted from different angles before (e.g. Klischewski 2001, Klischewski \& Wetzel 2001, 2002). Here we solely focus on the new challenges of process ownership according to the issues pointed out above. We examine to what extent the project management had succeeded in shifting the focus regarding process ownership tasks (as listed in table 3) and how reflecting process ownership issues had impacted the project management strategy. The case study is 
organized along the process ownership issues introduced in the tables 1 and 2 .

\subsection{Environment}

Following the vision of a one-stop government, the administration intended to provide also transaction services to be accessible through one single entry point. This entry point was meant to be the city's web portal at www.hamburg.de, which since 1999 has been provided by the private company hamburg.de. Thus, given the outsourcing arrangement already established, process management had to reach beyond the borders of the authority in charge, however without being able to draw on an existing technical and organizational infrastructure for this endeavor at that time.

Serious activities to realize the vision of a process portal for citizens started in October 2000. Encouraged by the finance department (being in charge of the city's egovernment strategy), a head of department in the "Senatsamt für Bezirksangelegenheiten" (SfB, the city's central administration for IT procedures, also responsible for supporting the temporary decentralized voting offices) was appointed to engage in a pilot project, and the citizens' application for postal vote was chosen as the first service to be supported through the web portal.

By the end of January 2001, the results of the first stage, including a prototype, were presented to members of SfB and of hamburg.de, to the city's election manager as well as the data protection commissioner. Shortly after that, requirements were specified (mainly concerning privacy and security issues) and a process was set up to get the service ready for the city state's elections in September 2001. However, a contract between SfB and hamburg.de was signed only after development was finished; and the informatics department of Hamburg University had separate consulting contracts with $\mathrm{SfB}$ and hamburg.de to support the distributed development process. In spring 2001, the enrollment of Microsoft Inc. was negotiated, but the company stepped back as it turned out that the technical solution suggested by the researches was not dedicated to promote the usage of their XML-based server products.

All partners acknowledged that, from the administrative point of view, the SfB was the owner of the postal vote application process. Basically, the scope of ownership (including end-to-end accountability) and a performance scheme were established well enough to secure this ownership. But since the SfB had only little experience with interorganizational projects, many details of setting up a favorable environment had not been foreseen (see below).

\subsection{Business Value}

From the administration point of view, the objective of the envisioned governmental process portal and the postal vote application service in particular was (a) to increase quality of service (new interactive, internet-based service channel) and (b) to reduce the cost level through involving the citizens in a part of the business process (for example, by keying in personal data themselves) and through facilitating IT-based cooperation between administrative units.

The interest of the portal provider hamburg.de was mainly to raise the attractiveness and user traffic of the website in general (in order to generate more value for commercial partners paying for the portal services). As transactions usually require some user specific data, several options for offering personalization facilities and even cross-selling have been considered.

Both the administration and the portal provider accepted to support the goals of the other partner respectively. Moreover, they agreed that creating value for the citizen is strategically important, e.g. reducing the application effort or introducing some interactive elements, while at the same time security and privacy have to be assured at a state-of-the-art level. The latter of course matched with the concerns of the city's election manager and the data protection commissioner who had also been involved in setting up this particular service.

All in all, understanding and mutual respect of the partners' business goals had been achieved; and the crossorganizational process management had increased the overall service capability and had finally led to successful service provision. However, there had been no assessment of risks and opportunities beforehand, and the city state government only slowly realized the costs of networking which countered the benefits of interorganizational cooperation (see also section 4.5).

\subsection{Process Specifications}

All partners involved accepted the concept of serviceflow management (Klischewski \& Wetzel 2001, 2002) as suggested by the researchers from univerity. Based on object-oriented, workflow and user-oriented modelling techniques, serviceflow patterns were modeled by identifying sequences of service points, each capturing the specific service tasks and their respective pre- and 
postconditions from the provider's point of view. Modeling serviceflow helps (1) to identify standardized portions (service points) of the overall service, (2) to allocate responsibility for the service at each point, and thus (3) supports co-operation across organizations and/or organizational units. The serviceflow management approach is designed for cooperative process networks and does not presuppose any form of overall process ownership.

For the postal vote application, four service points have been identified (each with related activities/operations in parentheses; see also figure 1):

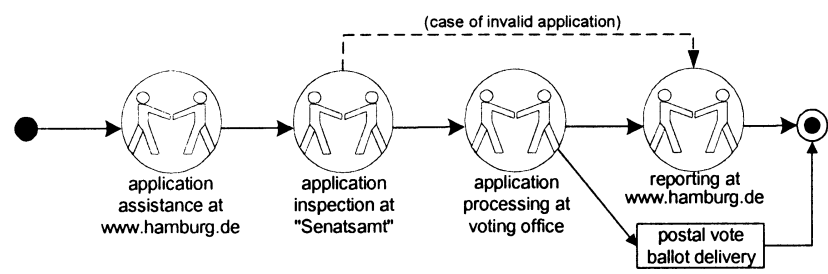

Figure 1. Serviceflow model for postal vote application

- providing assistance with the application for citizens at the city's web portal www.hamburg.de (opening application, automatic assistance in personalisation, on-site evaluation, confirming reception, serviceflow preview, offering/registering personal reporting channel, optional: saving application)

- inspecting the application at the SfB (automatic validity check including selecting the voting office in charge; or exception handling: selecting the voting office in charge if application processing seems possible - or moving directly to service point 4 in case of invalid application)

- processing of the application by the respective voting office (validity check with up-to-date preconditions, preparing personal postal vote ballot, notification of the electoral register, preparing postal vote ballot for dispatch, personalised exception handling if necessary)

- reporting on process by the web portal provider (delivering messages to inform the applicant about the state of the process, providing information about what to do next and/or whom to contact) through the channel the applicant has selected before (web page, email, SMS, etc.).

Other activities and operations not focusing on or reflecting the citizen's situated and personal need are considered support processes, in this case the delivery of the postal vote ballot by regular mail.

This mutual agreement on the process pattern (based on the serviceflow management approach) worked out fine for this case as it provided answers to almost all of the process ownership tasks on process specification (cf. table 1). However, in practice the project engagement as well as the service performance of hamburg.de fell short of the city's expectations. After all it turned out to be difficult for the administration to accept that the quality of administrative services now relied (partly) on one private company without any competitor in sight.

\subsection{Information technology}

On the way to establish appropriate IT support, questions of systems design and systems architecture had to be agreed on. Having just established the outsourcing arrangement for the portal hosting, there was no actor who was willing or able to forge an integrated system for the postal vote application service (i.e. a central database, file server, web portal, workflow engine, etc.). Thus, the cross-organisational transaction process management had to cross IT systems barriers. Those barriers included technical borders such as firewalls and incompatibilities between a web-oriented and a mainframe-oriented environment, but also non-technical barriers owing to the different locations, organisations, cultures etc. of the respective computing centres and IT departments.

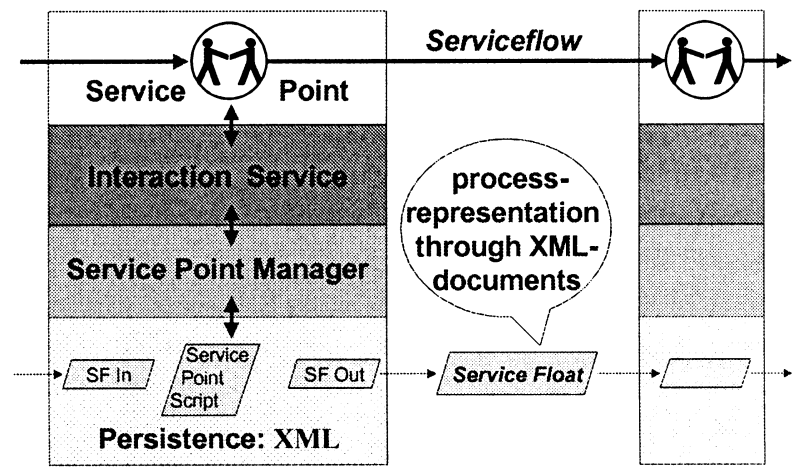

Figure 2. XML-based process communication within serviceflow management

The serviceflow management approach fitted well to settle these IT issues: for each case a XML-based "service float" is sent from service point to service point. Each individual "service float" (based on a general process related template) represents the relevant process information to be processed at each service point. Based on this each partner was free to implement the functional layers (serviceflow logic, interaction with browser or application 
system) according to available technology and given infrastructure restrictions (see figure 2).

Finally, to enable the cross-organizational processing the partners had to agree on the following (the first three suggested by the serviceflow management approach):

- a serviceflow model as a basis for the co-operative process management

- a set of XML DTD and XML "master"-documents

- a set of rules on how to manipulate and pass on the case-based XML documents

- a number of assertions concerning reliability, security, and privacy related to process performance

All of these issues have been documented and shared between the project partners.

The partners involved put high security demands on operating their back-end systems. Without being able to change directives within the partners' IT strategies, the barriers for interoperability remained high, requiring high effort overcome these barriers and/or to accept significant limitations in service quality. Additionally, during implementation of the service it turned out that the prospects for a common infrastructure are very limited since the city had started to plan for a transaction portal including a single sign-on gateway for personalized services - which will not be available for services hosted by hamburg.de. Thus, most of the process ownership tasks regarding information technology (cf. table 1) had been fulfilled even across the organizational borders, but the project management could not succeed in assuring an overall IT management and securing actors' commitments to setting up a common infrastructure.

\subsection{Transformation Process}

In early 2001 all parties involved agreed that the underlying concept of serviceflow management applies a general perspective and that the selected transaction process of applying for postal vote is only the first example that demonstrates the city's new e-government capabilities. All partners within the network saw the project as a learning vehicle to set up communication and cooperation in order to manage the cross-organizational and technical aspects of e-government transaction services within this network. It was acknowledged that due to administrative process ownership the SfB should be responsible for the overall project management.

In this case (which is typical for many e-government projects) the redesign of the business process did not mean to eliminate the old process. Even after introducing the service, the voting offices handle the majority of the cases all by themselves. However, in the redesigned process, the tasks to be fulfilled are split up between several service points; and each case of a citizen's application is handed over from the portal to the administration and back. The partners easily agreed on this basic structure, but since there was no centralized decision structure established to set up this case transfer, the partners negotiated in detail the terms of the process interfaces (frequency of data exchange, structure and quality of data, technical network issues, security, etc.) to find a balance concerning the effort each of the partner had to put into the business process.

From the organizational as well as from the technical point of view the serviceflow management approach proved to be successful for the particular service since after independent development of components the final testing required only a few minor adjustments.

However, all partners involved regarded the endeavor as a pilot project with the impact on organizational change only to be discussed after setting up the first service application. Thus, only a very few process ownership tasks concerning transformation (cf. table 1) had been addressed explicitly - even though (in retrospect) most of them turned out to be highly relevant. From the process owner point of view, mainly the following factors impeded the transformation towards a comprehensive interorganizational process management network:

- City officials stated several times that the effort to reach for a cooperative process management is quite high, and that they do not expect that this model will scale up, i.e. the rather small efficiency gains will justify the costs of interorganizational negotiation and cooperation.

- The partnership with hamburg.de within this project did not meet all the expectations; additionally the alliance turned out to be problematic in other fields of action as well.

- During systems development only the researchers were capable to obtain an overview on the state of development while at the same time they had no competencies for project management. The city had strategically decided to takes in most of the external IT products, developments and services from Microsoft Inc. Therefore, the city's overall e-government stepped back from relying on some individual researchers for providing process management and infrastructure solutions.

- The project included a practically irresolvable ambiguity of overall data ownership regarding the data submitted by citizens on the hamburg.de site - this could not be addressed due to the limitations of the 
interorganizational process ownership and it turned out to be not acceptable by the administration

\subsection{Epilogue}

The online service was successfully set up and operated for the 2001 city state elections, attracting some 10.000 users, with only very few user complaints and a very low error rate. The parties involved documented their achievements and options for continuing the effort in the direction of a full grown e-government process portal. The report was handed over to the city's e-government management.

The postal vote application service was put into operation again one year later for the national elections 2002. This time more than 25.000 citizens used the service (about $10 \%$ of all postal voters in Hamburg). This was done with no changes to the process and underlying agreements. The cooperation included only hamburg.de, but did not involve the university again.

Despite the successful operation it was decided not to continue this path. Instead, the city has started the implementation of a transaction portal with the possibility of executing complete control (without involvement of hamburg.de). In retrospect, the reasons for the discontinuation of this IT-enabled transformation of interorganizational process are related to the fact that some new challenges of process ownership have not been addressed properly. The SfB clearly had the responsibility of the postal vote application process - this worked out well for assuring correct processing of all applications and thus creating "business" value for all partners and customers (citizens) in the given and only slightly modified environment. However, the ownership of the interorganizational process was not reflected in other tasks related to process specification, information technology and transformation process.

In the end, the prospects for an interorganizational process ownership turned out to be limited which had not been realized by the administration when starting the project. Through the project, the city's e-government management had learned about the new tasks, challenges, costs and risks related to interorganizational process ownership - and stepped back to continue an intraorganizational process management, at least for the time being.

\section{Conclusion and Perspectives}

The contribution of this paper is primarily the identification of the changes in process ownership challenges when aiming at IT-enabled transformation of interorganizational business processes. A list of relevant process owner tasks has been provided, classified by different issues in which a shift in focus is suggested.

A case study of an e-government process portal served the purpose of exemplifying the novel process ownership challenges in an interorganizational context. Analyzing the case form the process ownership perspective reveals that the proposed shift of focus is indeed applicable and how neglecting these new challenges are a barrier for successful transformation.

So far, there is no recipe or guidance available how to proceed in these situations where the absence of an overall process ownership is not possible or not even desired. However, process ownership in an interorganizational context will always be inherently limited. Therefore, with the categorization and shift of focus suggested here, future research may investigate in more detail the dilemmas of distributed versus centralized ownership:

- Is a centralized overall process ownership an imperative for the redesign and IT support of interorganizational processes?

- Or are there organizational and technical means to compensate for its absence or even to take advantage of this kind of "anarchy"?

Most likely, practitioners would appreciate research to bring out different models of interorganizational process ownership and to discuss how to handle the related issues in an integrated way.

\section{REFERENCES}

[1] Aalst, W.M.P. van der (2000). Loosely Coupled Interorganizational Workflows: Modeling and Analyzing Workflows Crossing Organizational Boundaries. Information and Management 37: 67-75

[2] Aalst, W.M.P. van der, Kumar, A. (2003). XML Based Schema Definition for Support of Inter-organizational Workflow. Information Systems Research

[3] Aalst, W.M.P. van der, Moldt, D., Valk, R., Wienberg, F. (1999). Enacting Interorganizational Workflow Using Nets in Nets. In: Becker, J., zur Mühlen, M., Rosemann, M. (ed.). Workflow Management '99. Proceedings. University of Muenster, Information Systems Dep., Working Paper 70, pp. $117-136$

[4] Allen, R. (2000). Workflow: An Introduction. In Fischer, L. (ed.): Workflow Handbook 2001. Future Strategies, Lighthouse Point, FL, pp. 15-38

[5] Anderson, M.; Allen, R. (1999). Workflow Interoperability - Enabling E-Commerce. WfMC, http://www.wfmc.org/ standards/docs/IneropChallPublic.PDF

[6] Andrews, T., Curbera, F., Dholakia, H., Goland, Y., Klein, J., Leymann, F., Liu, K., Roller, D., Smith, D., Thatte, S., Trickovic, I., Weerawarana, S. (2003). Business Process Execution Language for Web Services (BPEL4WS). 
Version 1.1. BEA Systems, International Business Machines Corporation, Microsoft Corporation, SAP AG, and Siebel Systems; http://xml.coverpages.org/BPELv11May052003Final.pdf

[7] Bar, F. \& Borrus, M. \& Coriat, B. (1989). Information Networks and Competitive Advantage. Volume 1: Issues for Government Policy and Corporate Strategy Development. Berkeley Roundtable on the International Economy (BRIE), OECD/CEC DG XIII, Paris.

[8] Barret, S. \& Konsynski, B.R. (1982). Interorganization information sharing systems. MIS Quarterly, December.

[9] Basu, A., Kumar, A. (2002) Research Commentary: Workflow Management Issues in e-Business. Information Systems Research 13 (1): 1-14

[10] Benjamin, R.I. \& de Long, D.W. \& Scott Morton, M.S. (1990). Electronic Data Intechange: How Much Competitive Advantage?. Long Range Planning. Vol. 23(1), pp. 29-40.

[11] Champy, J. (2002). X-engineering the Corporation Reinventing Your Business in the Digital Age. Warner Business Books.

[12] Ciborra, C. (ed.) (2000). From Control to Drift. The Dynamics of Corporate Information Infrastructures. Oxford University Press

[13] Clarke, R. (1992). A contingency model of EDI's impact on industry sectors. Journal of Strategic Information Systems. Vol. 1(3), pp. 143-151.

[14] Clemons, E.K. \& Row, M.C. (1992). Information Technology and Industrial Cooperation: The Changing Economics of Coordination and Ownership. Journal of Management Information Systems. Vol. 9(2), pp. 9-28.

[15] Davenport, T. \& Short, J. (1990). The New Industrial Engineering: Information Technology and Business Process Redesign. Sloan Management Review. Summer, pp. 11-27.

[16] Davenport, T. (1993). Process Innovation: Reengineering work through Information Technology. Harvard Business School Press, Boston.

[17] Dijk, A. van (2003). Contracting Workflows and Protocol Patterns. Proceedings BPM 2003

[18] El Sawy, O.A. and Bowles, G. (1997). Redesigning the Customer Support Process for the Electronic Economy: Insights from Storage Dimensions. MIS Quarterly December 457-483.

[19] Grefen, P., Aberer, K., Hoffner, Y., Ludwig, H. (2000). CrossFlow: Cross-Organizational Workflow Management in Dynamic Virtual Enterprises. International Journal of Computer Systems Science \& Engineering 15 (5): 277-290

[20] Hammer, M. \& Stanton, S. (1999). How Process Enterprises Really Work. Harvard Business Review, November-December, pp. 108-118.

[21] Hammer, M. \& Stanton, S.A. (1995). The Reengineering Revolution. Harper Business.

[22] Hammer, M. (1990). Reengineering Work: Don't Automate, Obliterate. Harvard Business Review. JulyAugust, pp. 104-112.
[23] Hammer, M. (1996). Beyond Reengineering. Harper Collins Publishers. N.Y.

[24] Hammer, M. (2001a). The Agenda - What Every Business Must Do to Dominate the Decade. Random House Business Books.

[25] Hammer, M. (2001b). The Superefficient Company. Harvard Business Review. September, pp. 82-91.

[26] Hammer, M. (2002). Process Management and the Future of Six Sigme. MIT Sloan Management Review. Winter, pp. 26-32.

[27] Hammer, M. and Champy, J. (1993). Reengineering the Corporation - A Manifesto for Business Revolution. Harper Collins Publishers, New York.

[28] Holland, C.P. \& Lockett, A.G. (1993). Forms of association in business markets: the impact of interorganisational systems. In Sharma, D.D. (edit.). Advances in International Marketing. Vol. 5, JAI Press, Greenwich, CT, pp. 125-143.

[29] Holland, C.P. (1995). Cooperative Suply Chain Management: The impact of Interorganisational Information Systems. Journal of Strategic Information Systems. Vol. 4(2), pp. 117-133.

[30] Jacobson, I. (1992). Object-Oriented Software Engineering. Harlow, England: Addison-Wesley/ACM Press.

[31] Johnston, H.R. \& Vitale, M.R. (1988). Creating Competitive Advantage with Interorganisational Information Systems. MIS Quarterly. Vol. 12(2), pp. 153166.

[32] Kambil, A. \& Short, J.E. (1994). Electronic Integration and Business Network Redesign: A Roles-Linkage Perspective. Journal of Management Information Systems. Spring, Vol. 10(4), pp. 59-83.

[33] Keen, P. \& McDonald, M. (2000). The eProcess Edge Creating Customer value and business wealth in the Internet Era. Osborne. McGraw-Hill.

[34] Klischewski, R. \& Wetzel, I. (2001). XML-based Process Representation for e-Government Serviceflows. In: Schmid, B., et al. (ed.): Towards the E-Society: Ecommerce, E-business, and E-government (I3E 2001, IFIP). Dordrecht: Kluwer, pp. 789-802.

[35] Klischewski, R. (2001). Infrastructure for an e-Government Process Portal, In: Remenyi, D., Bannister, F. (ed.): European Conference on e-Government. MCIL, Reading, UK, pp. 233-245.

[36] Klischewski, R. (2001a). Commitments Enabling Cooperation in Distributed Information Systems Development, Proceedings 9th European Conference on Information Systems (ECIS 2001, Bled, Slovenia, June 2729), pp. 509-519.

[37] Klischewski, R., Wetzel, I. (2002). Serviceflow Management: Caring for the Citizen's Concern in Designing E-Government Transaction Processes. Proceedings of the 35th Hawaii International Conference on System Sciences (HICSS-35). IEEE

[38] Konsynski, B.R. \& McFarlan, F.W. (1990). Information Partnerships - Shared Data, Shared Scale. Harvard Business Review. September-October, pp. 114-120. 
[39] Krcmar, H. \& Bjørn-Andersen, N. \& O'Callaghan, R. (eds.). (1995). EDI in Europe - How it works in practice, Wiley, Chichester.

[40] Larsen, M.H. \& Bjørn-Andersen, N. (2001). From Reengineering to Process Management - A Longitudinal Study of BPR in a Danish Manufacturing Company. In Proceedings of the 34th Hawaii International Conference on System Sciences (HICSS 34). January 3-6, 2001, Island of Maui, Hawaii, USA.

[41] Larsen, M.H. \& Leinsdorff, T. (1998). Organisational Learning as a Test-Bed for Business Process Reengineering. Proceedings of the $31 \mathrm{st}$ Hawaii International Conference on System Science (HICSS'98), January 6-9, The Big Island of Hawaii, Hawaii, USA. Vol. 5, 343-354

[42] Larsen, M.H. (2002). Learnings from CALS in Reengineering. Proceedings of the International Association of Science and Technology for Development (IASTED) International Conference on Communications, Internet and Information Technology (CIIT 2002). November 18-20, St. Thomas, Virgin Islands, USA, pp. 67-74.

[43] Larsen, M.H.; L.R. Franck, and Pedersen, M. Kühn. (1999). Frontline CALS - Extranet Enabled Support of Customer Relations Based on Product State Information. Proceedings of the 7th European Conference on Information Systems. Copenhagen, June, 302-319.

[44] Lee, H. \& Clark, T. (1996). Market Process Reengineering Through Electronic Market Systems: Opportunities and Challenges. Journal of Management Information Systems, Vol. 13(3), pp. 113-136.

[45] Lienhard, H. (2003). Web Services and Workflow - a Unified Approach. In: Fischer, L. (ed.). The Workflow Handbook 2003. Lighthouse Point, FL: Future Strategies

[46] McFarlan, F.W. (1984), Information Technology Changes The Way You Compete, Harvard Business Review, MayJune, 98-103

[47] Meier, J. \& Spargue, R.H. (1991). The Evolution of Interorganisational Systems. Journal of Information Technology. Vol. 6(3), pp. 184-191.

[48] Meier, J. (1995). The Importance of Relationship Management in Establishing Successful Interorganisational Systems. Journal of Strategic Information Systems. Vol. 4(2), pp. 135-148.

[49] Moorman, C \& Zaltmann, G. et al. (1992). Relationships between Providers and Users of market Research: The Dynamics of Trust within and Between Organizations. Journal of Marketing Research. Vol. 29, pp. 314-328.

[50] Mukhopadhyay T. Kekre S. and Kalathur S. (1995) Business value of information technology: A study of electronic data interchange. Management Information Systems Quarterly, June, pp. 137-156.

[51] Nygaard-Andersen, S. \& Bjørn-Andersen, N. (1994). To Join or Not to Join: A Framework for Evaluating Electronic Data Interchange Systems. Journal of Strategic Information Systems. Vol. 3(3), pp. 1991-210.
[52] Oliver, C. (1990). Determinatns of Interorganisational Relations: Integration and future directions. Academy of Management Review. Vol. 15(2), pp. 241-265.

[53] Porter, M.E. \& Millar, V.E. (1985). How Information Gives You Competitive Advantage. Harvard Business Review. July-August, pp. 149-160.

[54] Porter, M.E. (1979). How Competitive Forces Shape Strategy. Harvard Business Review. March-April, pp. 137-145.

[55] Porter, M.E. (2001). Strategy and the Internet. Harvard Business Review. March, pp. 63-78.

[56] Ramanath, A.M., Paul, R.J., Macredie, R. (1997). The Role of the Software Life Cycle in the Development of Interorganisational Systems. Proceedings $3^{\text {rd }}$ Americas Conference on Information Systems. Association for Information Systems (AIS)

[57] Rogers, D.S. \& Daugherty, P.J. \& Stank, T.P. (1992). Enhancing Service Responsiveness: The Strategic Potential of EDI. International Journal of Physical distribution \& Logistics Management. Vol. 22(8), pp. 15-20.

[58] Schnitt, D.L. (1993), Reengineering the Organisation Using Information Technology, Journal of Systems Management, January, pp. 14-22, 41-42.

[59] Short, J. \& Venkatraman, N. (1992). Beyond Business Process Redesign: Redefining Baxter's Business Network. Sloan Management Review, Autumn, Vol. 34(1), pp. 7-21.

[60] Skagen, A.E. (1989). Nurturing Relationships, Enhancing Quality with Electronic Data Interchange. Management Review, pp. 28-32 February.

[61] Swatman, P.M.C. \& Swatman, P.A. (1992). EDI System Integration: A Definition and Literature Survey. The Information Society. Vol. 8, pp. 169-205.

[62] Venkatraman, N., IT-Enabled Business Transformation: From Automation to Business Scope Redefinition. Sloan Management Review, 35, Winter 73-87. 1994.

[63] Webster, J. (1995). Networks of Collaboration or Conflict? Electronic Data Interchange and Power in the Supply Chain. Journal of Strategic Information Systems. Vol. 4(1), pp. 31-42.

[64] Weerakkody, V., Currie, W. (2003). Integrating Business Process Reengineering with Information Systems Development - Issues \& Implications. Proceedings BPM 2003

[65] Wetzel, I., Klischewski, R. (2002). Serviceflow beyond Workflow? Concepts and Architectures for Supporting Inter-Organizational Service Processes, In: Advanced Information Systems Engineering. Proceedings 14th CAiSE. Springer Lecture Notes in Computer Science, Berlin, pp. 500-515.

[66] Williams, T. (1997). Interorganisational Information Systems: Issues Affecting Interorganisational Cooperation. Journal of Strategic Information Systems. Vol. 6, pp. 231250.

[67] Zhao, J.-L. (2002). Workflow Management in the Age of E-Business. Tutorial at the 35th Hawaii International Conference on System Sciences. Jan. 4th. Waikoloa, Hawaii; http://attila.stevens-tech.edu/sigpam/publications/ tutorial/HICSS-35/Interorganizational_Workflow.pdf 